\title{
STUDYING THE SIMULTANEOUS EFFECT OF BLACK NANOCARBON AND POLYESTER FIBERS WITH HIGH STABILITY ON MECHANICAL PROPERTIES OF ASPHALT MIXTURE
}

\author{
Mohsen Zahedi \\ Department of Civil Engineering, Razi university, Iran \\ Mohammad Zarei \\ Technical College, Institution of Civil and Development \\ zahedi@razi.ac.ir
}

\begin{abstract}
Undoubtedly, making asphalt mixture with good quality has been always considered by road constructor engineers. In this research, by adding different percent amounts of black nanocarbon and polyester fibers jointly in asphalt mixture and doing Marshall tests, data analysis and drawing necessary diagrams, it was observed that adding these two additives causes the changes on Marshall Results. The results indicated that Marshall Stability of made samples with joint effect of additives in a special percent is increased to $71 \%$. With increasing of stability, fluidity was also increased. Total volume of asphalt mixture (VTM) in most of percent amounts was increased relatively. On the other hand, special weight of asphalt mixture in all percent amounts (except a special percent) was reduced. Finally void volume of aggregates (VMA) was increased relatively and the percent of space filled with bitumen (VFA) except a special percent was reduced. By studying and analyzing the diagrams, optimum percent for combination of black nanocarbon and polyester fibers with high stability was obtained in order $15 \%$ black nanocarbon and $\% 0.5$ polyester fibers with high stability which has had the best effect on asphalt mixture. Finally, it was concluded that the obtained mixture can be used in the regions with moderate weather and heavy traffic.
\end{abstract}

Keywords: black nanocarbon, asphalt, polyester fibers, pavement, Marshall

\section{ASFALT KARIŞIM MEKANIKK ÖZELLİKLERİNE YÜKSEK KARARLILIK ILE SIYAH NANOKARBON VE POLYESTER LIFLİ AYNI ANDA ETKISIININ İNCELENMESI}

ÖZ

Kuşkusuz, kaliteli yapım asfalt karışımı her zaman yol yapıcı mühendisleri tarafından kabul edilmiştir. Bu araştırmada, ortaklaşa asfalt karışımında siyah nanocarbon ve polyester liflerinin farklı yüzde miktarlarının eklenmesi ve Marshall testleri, veri analizi yapıyor ve gerekli diyagramları çizerek, bu Marshall Sonuçları bu iki katkı ekleyerek değişikliklere neden olduğu gözlenmiştir. Sonuçlar özel yüzde katkı ortak etkisi ile yapılan örneklerin Marshall Stabilite\% 71 arttırılır olduğunu göstermiştir. stabilite artan akışkanlık da yükseltildi. Yüzde miktarlarının en asfalt karışımı (VTM) toplam hacmi göreceli olarak arttırılmıştır. Öte yandan, (özel bir yüzde hariç), yüzde miktarları asfalt karışımının, özel ağırlığı azaltıldı. Son olarak agrega boşluk hacmi (VMA), nispeten artmış ve özel bir yüzdesi hariç bitüm (VFA) ile doldurulmuş boşluk yüzdesi düşürülmüştür. eğitim ve diyagramları analiz ederek, yüksek stabilite siyah nanocarbon ve polyester liflerinin kombinasyonu için uygun yüzde sırası $\% 15$ siyah nanocarbon asfalt karışımının en iyi etkiye sahip olan, yüksek stabilite ile\% 0.5 polyester lif elde edildi. Son olarak, elde edilen karışım, orta hava ve yoğun trafik olan bölgelerde kullanılabilir olduğu sonucuna varıldı.

Anahtar kelimeler: siyah nanocarbon, asfalt, polyester elyaf, kaldırım, Marshall 


\section{INTRODUCTION}

Strengthening the asphalt mixture by using of additives has been considered in recent years by road constructor engineers. They have applied different additives to the bitumen and asphalt mixtures for improvement of pavement performance.

In this article, nanotechnology (black nanocarbon) and fibers (polyester fibers with high stability) were used for strengthening the asphalt mixture. Also for making the samples, asphalt mixture with solid granulation and according to ASTM standard was used.

\section{A REVIEW ON STUDY LITERATURE}

\section{- Nanotechnology}

Nanotechnology means the technology of one-billion of meter or the atoms technology. This size means 50000 times thinner than thickness of a hair strand which is equal to several atoms.

Sheng Zhao \& et $\mathrm{al}^{1}$ (2014) have done a laboratory study on the bio-flux effect on asphalt mixture. The amounts of black carbon added in this research were 5 and $10 \mathrm{wt} \%$ of bitumen. At first, they modified bitumen with black carbon and then they added the modified bitumen to the materials. The results indicated that adding this additive has positive effect on Marshall Tests [8].

\section{1-Sheng Zhao, Baoshan Huang, Xiang Shu, and Philip Ye.}

In the research of Khalida binti Khalid (2013), two kinds of black carbon including raven-3500 and n220 for strengthening the bitumen type 60.70 have been used. Black carbon with the weight ratio of $4 \%$ bitumen was added to the bitumen. The results of influence test and softness point in this research indicate the reduction of influence degree and increasing of softness point [4].

In a research, using of pyrolized black carbon (PCB) from wasted rubbers on asphalt pavement was researched. Pyrolized method is the decomposition of rubbers with a baking process in order to break the rubber into the secondary salable materials and includes $55 \%$ oil, $25 \%$ black carbon, $9 \%$ steel, $5 \%$ fiber and $6 \%$ gas. They studied a comparative effect with mentioned issue in their research and it was the effect of black carbon on bitumen AC-10 and AC-20. The results indicated that black carbon in lower percent amounts hasn't had much effect on stability but in high percent amounts, stability will be increased [Taesoon Park, C. W. Lovell, 1996].

\section{- Fibers}

Manoj Shukla \& et al ${ }^{1}$ did a comparative study about the effect of polyester fibers and glass fibers for strengthening the asphalt mixture. The selected length of polyester fibers for using in project was $8 \mathrm{~mm}$. The weight percent used in the project was $0.20 \mathrm{wt} \%$ of asphalt. The tests results indicated that Marshall Stability causes an increase about \%13 for polyester fibers [5].

Bowen Guan \& et $\operatorname{al}^{2}(2014)$ in a laboratory work studied some kinds of fibers for strengthening the asphalt mixture. The length of used fibers was $6 \mathrm{~mm}$ and $0.25 \mathrm{wt} \%$ of asphalt weight was used. The tests results indicated that adding polyester fibers with high conditions increases Marshall Stability about $13 \%$ [3]. As it was mentioned above, the effect of black nanocarbon additive and polyester fibers has been studied only on asphalt; but in this research for the first time, the joint effect of black nanocarbon and polyester fibers with high stability on asphalt mixture was studied.

\section{MATERIALS AND METHODS MATERIALS}

The needed materials in this research were in order bitumen, aggregates, polyester fibers with high stability and in order they will be explained in the following.

\section{BITUMEN}

In order to study the additives effect on mechanical properties of asphalt mixture, asphalt samples were made from 8-100 standard bitumen of Kermanshah's refinery. Granulation of aggregates, kind and properties of black nanocarbon and polyester fibers with high stability and the manner of making asphalt samples have been mentioned in the following.

AGGREGATES

The granulation curve obtained from mixing the needed weight percent amounts in comparison with granulation applied in providing the samples has been drawn in the shape 1 .

1- Manoj Shukla, Dr. Devesh Tiwari, and K. Sitaramanjaneyulu

2- Bowen Guan, Rui Xiong, Rui He, Shuanfa Chen, and Donghai Ding 


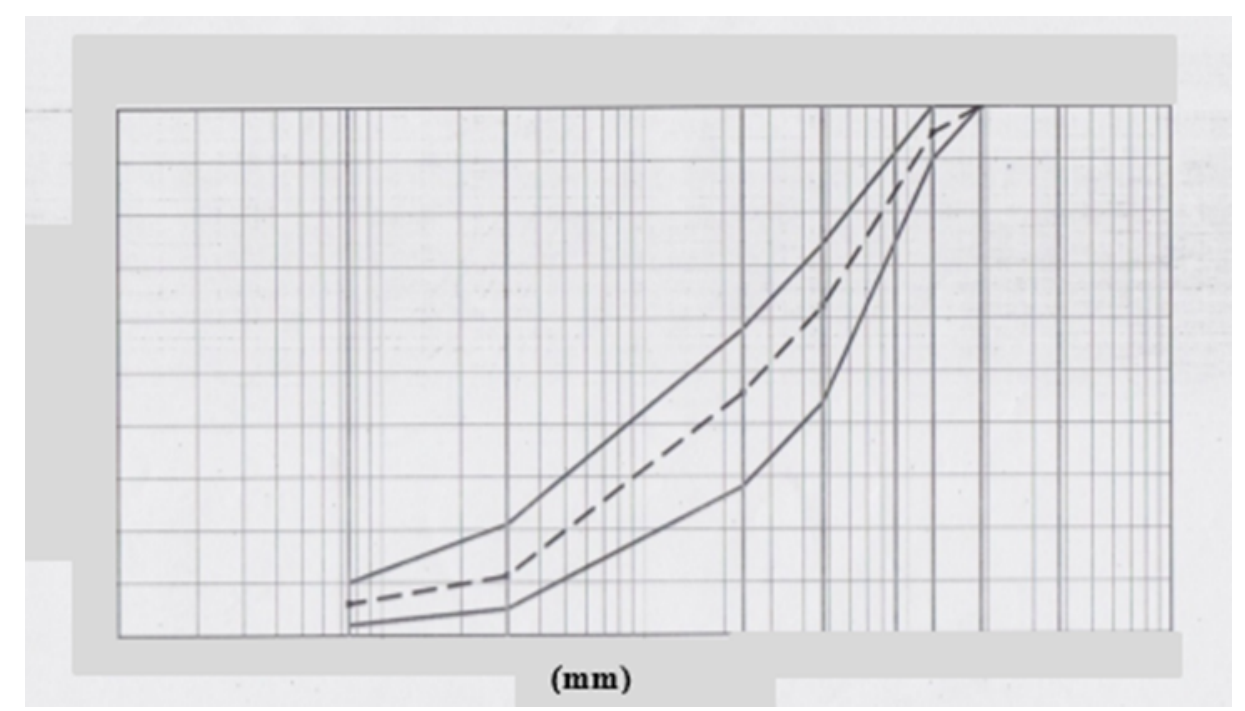

Shape 1. Granulation of asphalt mixture aggregates of Topeka layer, 0-19mm

\section{3-Consumed Black Nanocarbon}

As it was mentioned in the previous parts, the size of black carbon is classified into different types. Black carbon in this research is from Cas no.1333-86-4 type that its specifications have been mentioned in the table 1.

Table 1. specifications of consumed black carbon

\begin{tabular}{|c|c|c|c|c}
\hline Classification & $\begin{array}{c}\text { Density bulk } \\
\left(\mathrm{g} / \mathrm{cm}^{3}\right)\end{array}$ & $\begin{array}{c}\text { Surface area } \\
\left(\mathrm{m}^{2} / \mathrm{g}\right)\end{array}$ & $\begin{array}{c}\text { Size(range }) \\
(\mathrm{nm})\end{array}$ & $\begin{array}{c}\text { Size used } \\
(\mathrm{nm})\end{array}$ \\
\hline Cas no. 1333-86-4 & 0.21 & 80 & $15-300$ & 42 \\
\hline
\end{tabular}

\section{4- Polyester Fibers With High Stability}

In this project, polyester fibers with high stability were used, they were provided from tire Cord Company in Kermanshah and they are applied for strengthening the vehicles' rubber. In Iran, these types of fibers in filamentous form for strengthening the asphalt mixture haven't been still used. The fibers used in this project were from fibers with scores of 2200 and 1440 which were used in combinative form. The Denier amounts of them are in order 1980 and 1300 gram. Since these fibers have been used in asphalt dispersedly, so tonicity is the determining factor. Some of the properties of this kind of fibers have been mentioned in the table 2.

Table 2. specifications of polyester fibers used in this project

\begin{tabular}{ccccc}
\hline $\begin{array}{c}\text { Melting } \\
\text { point } \\
\left({ }^{\circ} \mathrm{C}\right)\end{array}$ & $\begin{array}{c}\text { Tonicity or the } \\
\text { breaking stress } \\
(\mathrm{cN} / \text { tex })\end{array}$ & $\begin{array}{c}\text { Tonicity or the breaking } \\
\text { stress } \\
(\mathrm{gr} / \text { denier })\end{array}$ & $\begin{array}{c}\text { Force in the breaking } \\
\text { point } \\
\text { b.s }\end{array}$ & $\begin{array}{c}\text { denier } \\
(\mathrm{gr})\end{array}$ \\
\hline $\mathbf{2 6 0 - 2 5 0}$ & 75 & 7 & 154 & 1300,1980
\end{tabular}

Chemical formula of PET polyester fibers is in the form of shape 3:

Polyethyleneterephthalate;PET<smiles>COCCOC(=O)c1cccc(C(C)=O)c1</smiles>

MAKING THE SAMPLES

Shape 3. Chemical formula of polyester fibers 
At first, we pour the aggregates inside a dish after granulation and add the fibers in filamentous form and with high accuracy to the materials and then we put the obtained set in the oven. Also we heat the bitumen used in this project up to $150^{\circ} \mathrm{c}$ and then we add black nanocarbon to the fluid bitumen slowly. Finally the materials in this set are mixed with each other so that bitumen covers all surfaces of aggregates.

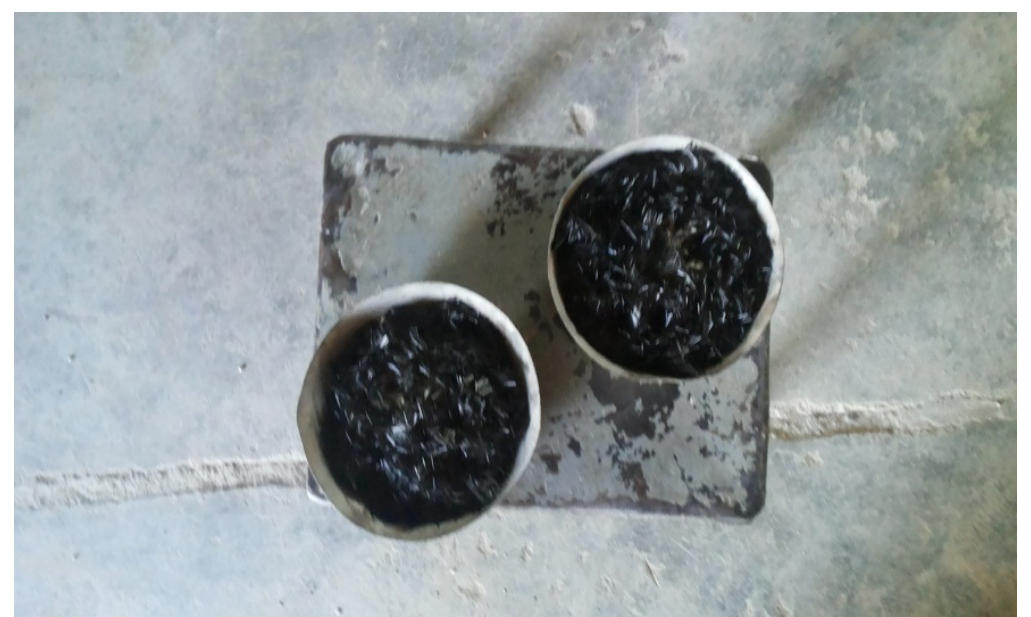

\section{DOING THE TEST}

Shape 2. Mixture obtained from the additives effect

The method of making and designing the asphalt mixture was done according to the standard method of ASTM-D1559. For influencing both additives, at first the effect of polyester fibers on materials is studied in a manner that the extreme point of Marshall stability for different percent amounts of polyester fibers is obtained. Then the intended percent amounts are combined with different percent amounts of black nanocarbon so that the best results are obtained. With regard to this issue that the materials were related to the mixture design of Sanandaj municipality in 2014, so the optimum bitumen percent was available; therefore for optimum percent amounts of $0.5,1,1.5$ and 3 percent of polyester fibers with high stability and also for $5,10,15$ and 20 percent of black nanocarbon, asphalt sample in this research was made and Marshal tests were done on it.

\section{THE ANALYSIS OF MARSHAL STABILITY RESULTS}

As it has been indicated in the shape 3, joint combination of both of them has caused to increase its Marshal stability, so that adding $15 \%$ of black nanocarbon and $1.5 \%$ of fibers has led to a stability equal to 1427 which indicates an increase of $71 \%$ stability compared with the base sample. Also adding $15 \%$ of black nanocarbon and $0.5 \%$ of fibers has led to a stability equal to 1305 which indicates an increase of $56 \%$ stability compared with the base sample.

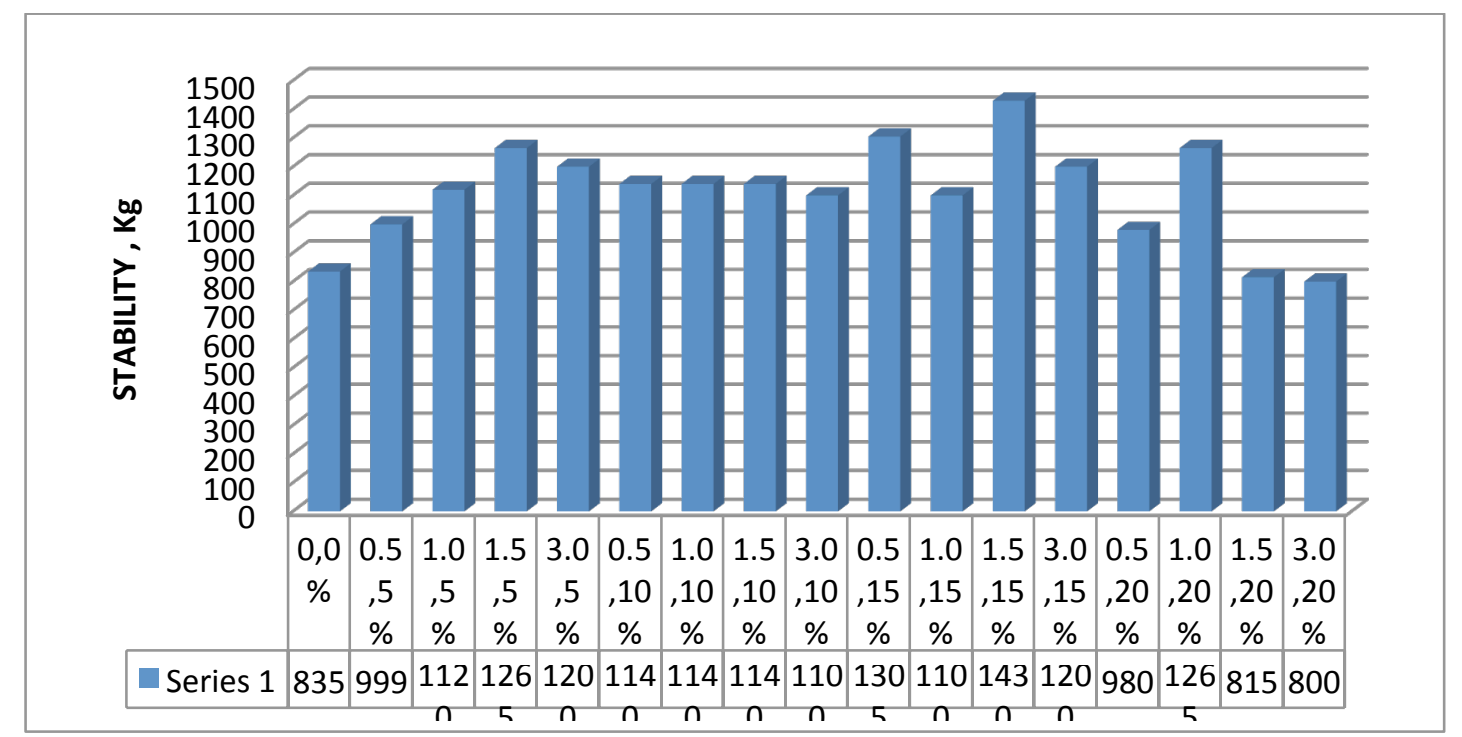


Shape 3. The effect of different percent amounts of black nanocarbon and polyester fibers jointly on Marshall Stability

THE ANALYSIS OF MARSHAL FLUIDITY RESULTS

With regard to the diagram and the tests results obtained in percent amounts of 5,15\% of soot with increasing of fibers percent, fluidity is increased so that in 5\% soot ,3\% fibers and $15 \%$ soot, $3 \%$ fibers, fluidity has been increased about $166 \%$ compared with the base sample. Also in the percent amounts of 10 and $15 \%$ soot and with increasing of fibers percent, fluidity is reduced so that in $10 \%$ soot and 3\% fibers, fluidity has been reduced about 14\% (shape 4). The cause of this difference probably has been related to the chemical reactions or the manner of absorption of black noanocarbon and polyester fibers to the consumed bitumen.

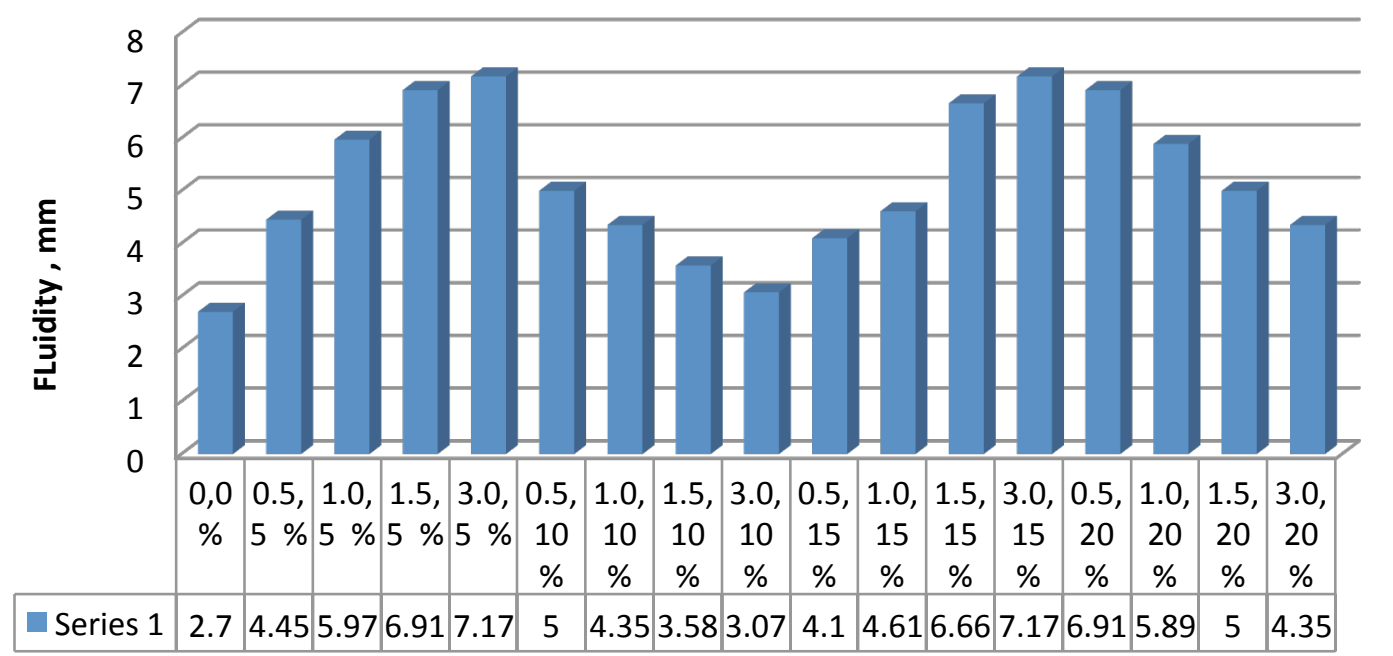

Shape 4. The effect of different percent amounts of black nanocarbon and polyester fibers jointly on fluidity

VTM RESULTS ANALYSIS

According to the shape 6 , in the percent amounts of $3 \%$ fibers and $10 \%$ black nanocarbon, about $102 \%$ increase of total void volume of mixture in comparison with the base sample was observed. This result is more influenced from the presence of polyester fibers resistant to black nanocarbon (due to higher special level).

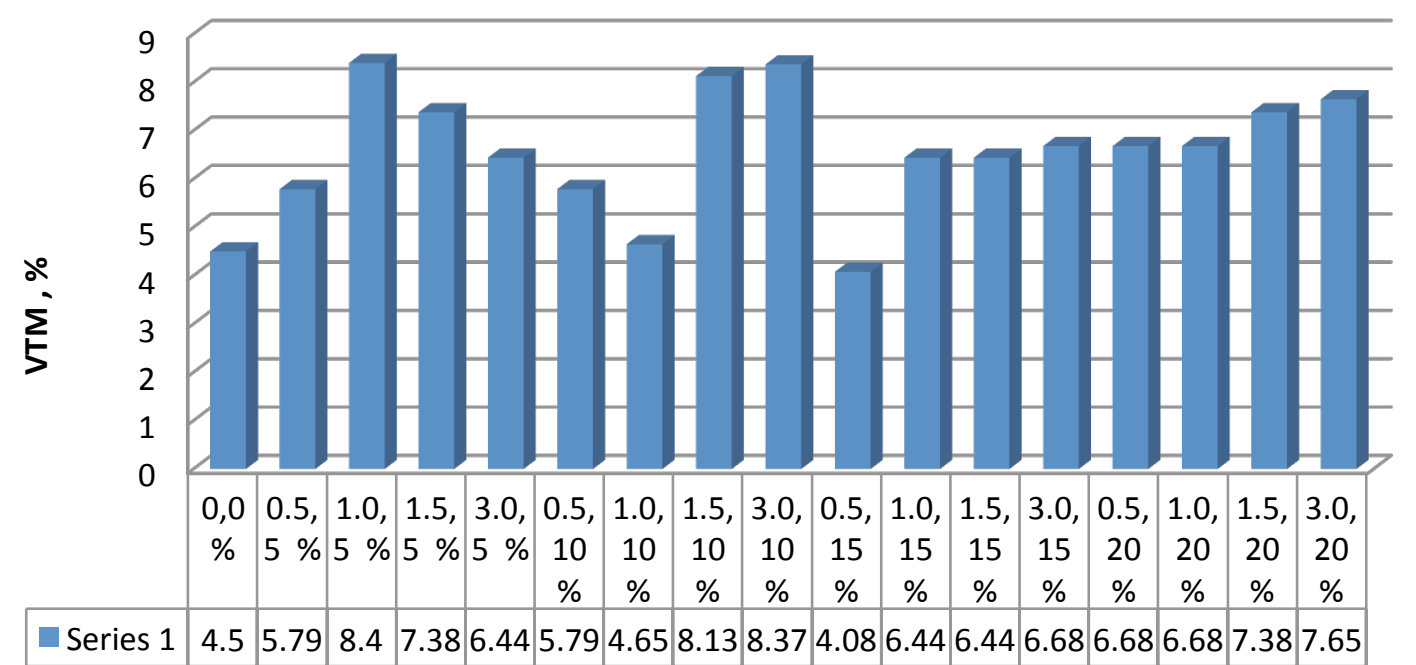

Shape 5. The effect of different percent amounts of black nanocarbon and polyester fibers on VTM

ANALYSIS OF SPECIAL WEIGHT RESULTS

As it is observed in the shape 6 , there is not a special order in increasing and reducing the special weight. This result is due to the different effects of additives on the sample lonely. $0.5 \%$ polyester fibers and $15 \%$ black nanocarbon are the only percent amounts in which special increase is seen. It 
seems this increase is related to more role of polyester fibers than black nanocarbon in the mixture (stronger presence of polyester fibers due to less special weight than black nanocarbon).

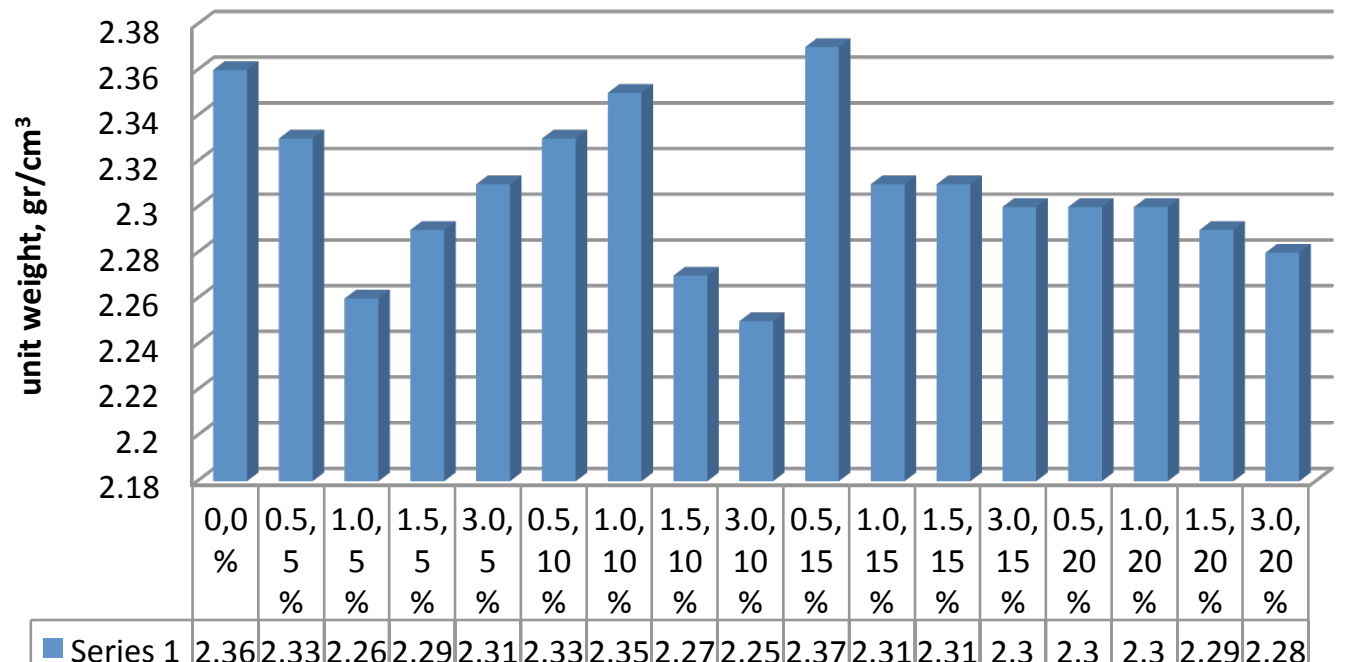

Shape 6. The effect of different percent amounts of black nanocarbon and polyester fibers on

VMA RESULTS ANALYSIS

special weight

Relative increase in the shape 7 is seen obviously. It seems this increase is related to more role of polyester fibers than black nanocarbon in the mixture (stronger presence of polyester fibers due to higher special level).

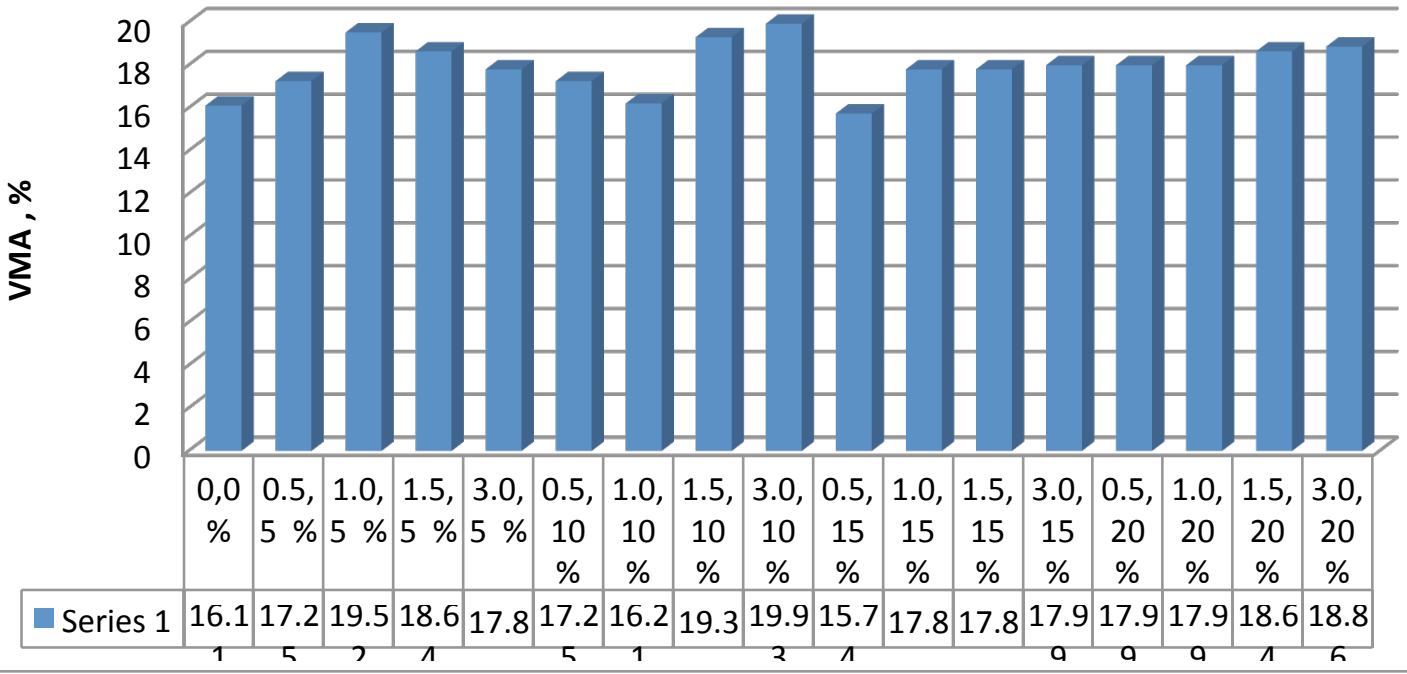

Shape 7. The effect of different percent amounts of black nanocarbon and polyester fibers on VMA

VFA RESULTS ANALYSIS

According to the results and shape 8 , in $0.5 \%$ fibers and $15 \%$ black nanocarbon, an increase about $3 \%$ was observed. On the other hand, in 3\% fibers and $10 \%$ black nanocarbon, a reduction about $25 \%$ was obtained. As it is obvious, the diagram shape is imbalanced, but generally joint effect has caused to reduce VFA amount. 


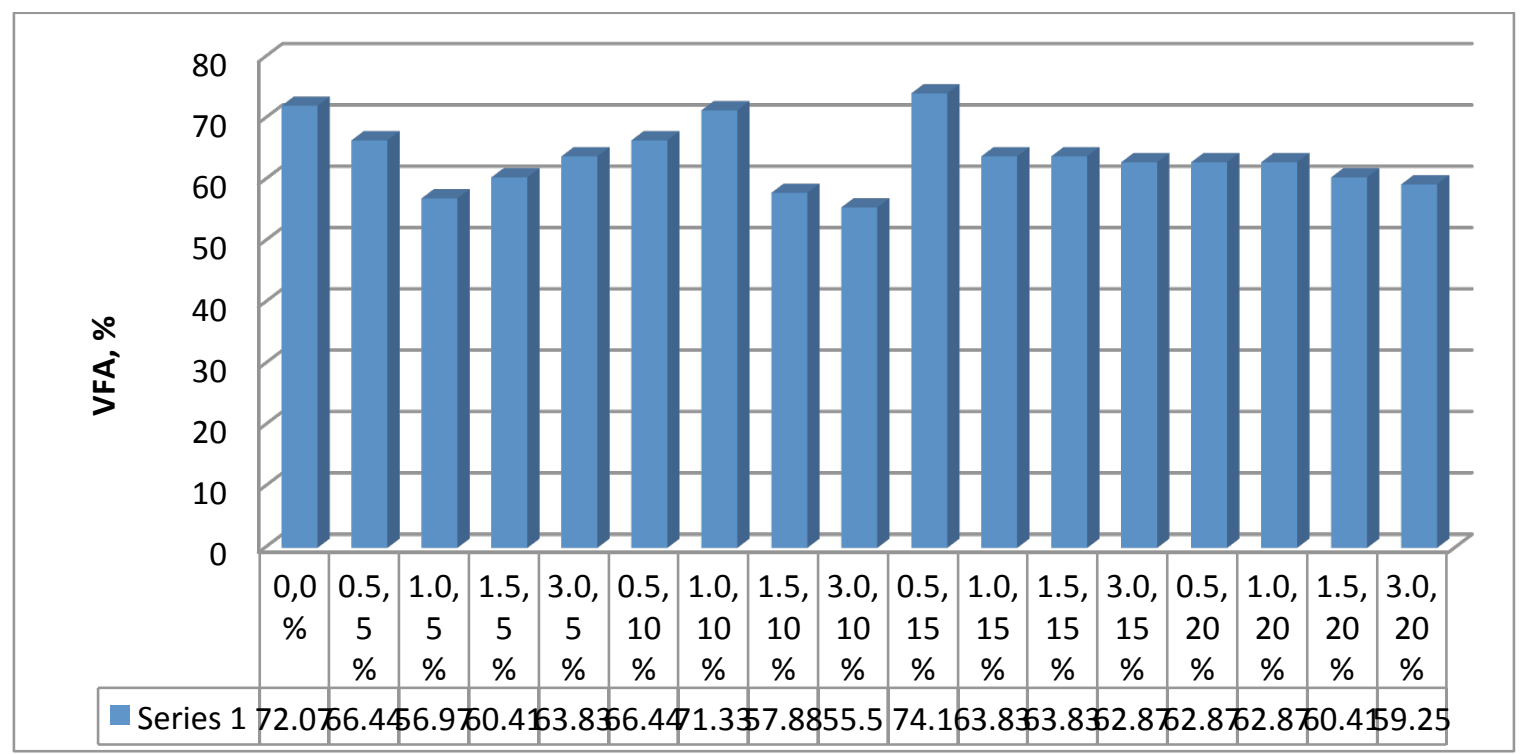

Shape 8. The effect of different percent amounts of black nanocarbon and polyester fibers on VFA

\section{CONCLUSION}

Since polyester fibers with high stability and in filamentous form with black nanocarbon were used in this research, it is a new research in the world and consequently the results obtained from the tests need more deliberation and inference. But what is indisputable is the positive and acceptable effect on Marshall Stability and fluidity. The results are summarized in the following:

1)Marshall stability in the state of combining two additives is increased so that in the event of adding 1.5 percent polyester fibers and $15 \%$ black nanocarbon, a stability equal to $1427 \mathrm{~kg}$ has been recorded which indicates the stability has been increased $71 \%$ compared with the witness sample.

2) With regard to the test results and considering the mix of black nanocarbon with bitumen and also absorption of fibers to aggregates, in percent amounts of 5 and 15\% black nanocarbon with increasing of fibers percent, fluidity is increased so that in 3\% nano and 3\% fibers and also $15 \%$ nano and $3 \%$ fibers, fluidity has been increased about $166 \%$ compared with the base sample. Also in percent amounts of 10 and $15 \%$ nano and with increasing of fibers percent, fluidity is reduced so that in $10 \%$ nano and 3\% fibers, fluidity has been reduced about $14 \%$. As it is observed, no special order is seen in this issue that probably will be related to the manner of absorption of black nanocarbon to bitumen and fibers to the materials and bitumen.

3 ) In the ratios of $3 \%$ fibers and $10 \%$ black nanocarbon, about $102 \%$ increase of total void volume of mixture compared with the base sample was observed. Due to the increase of VTM in this point, it seems polyester fibers have stronger role than black nanocarbon in the mixture.

4) The changes of special weight of samples with increasing of joint percent of black nanocarbon and fibers haven't had a special form and this was due to the different effects of black nanocarbon and fibers on asphalt sample. It seems here the effect of polyester fibers is also stronger than black nanocarbon.

5) With regard to this issue that the joint effect of both materials was different on asphalt mixture properties, different results were obtained. Due to the increase of VMA in this part, it seems polyester fibers have stronger role than black nanocarbon in the mixture.

6) In adding both materials in combinative form and in $0.5 \%$ fibers and $15 \%$ black nanocarbon, an increase about 3\% was observed. On the other hand in 3\% fibers and 10\% black nanocarbon, a reduction about $25 \%$ was obtained. As it was mentioned, the diagram shape was imbalanced. But general reduction was seen in the joint effect which indicates stronger role of polyester fibers than black nanocarbon in the mixture.

This research for the first time studied the joint effect of two additives that their results were expressed separately. With regard to the results, adding black nanocarbon as much as $15 \%$ and fibers as much as $0.5 \%$ has the best effect on the mixture so that the obtained mixture can be used in the 
moderate regions due to the increase of fluidity and in the regions with much traffic due to high stability.

What is indisputable, for obtaining the best results, doing different researches and tests is recommended as follows:

$\checkmark$ Using of another combination of nano-materials and fibers with different percent amounts in asphalt mixture.

$\checkmark$ Studying the effects of polyester fibers and black nanocarbon on the tests like transient modulus, indirect tension,...

$\checkmark$ Using of different percent amounts of bitumen for combining these two additives in asphalt mixture.

$\checkmark$ Obtaining optimum bitumen percent for each joint percent of these two additives.

$\checkmark$ Using of fibers with different lengths in asphalt mixture

$\checkmark$ Using of XRD photography for recognition of chemical reactions in the mixture.

\section{REFERENCES}

[1] Transportation research institute (2008), "asphalt mixtures with high stability against rutting". Department of transportation; Tehran, Iran.

]2[ Asphalt Institute. ) 1984(“Mix Design Method For Asphalt Concrete And Other Hot-Mix Types" (MS-2).

]3[ Bowen Guan, Rui Xiong, Rui He, Shuanfa Chen, and Donghai Ding (2014)"Investigation of Usability of Brucite Fiber in Asphalt Mixture".

]4[ Khalida binti Khalid, )2013( "The Physical and Engineering Properties of 70/60 Bitumen with Carbon Black Additives".

] 5[Manoj Shukla, Devesh Tiwari, K. Sitaramanjaneyulu, (2014)"Performance characteristics of fiber modified asphalt concrete mixes", The International Journal of Pavement Engineering and Asphalt Technology (PEAT) ISSN 8164 1464. Volume: 15, Issue: 1, May 2014, pp50 $38 .$.

]6[ Neman, k. )2004( "Polymer-Modified Asphalt Mixtures For Heavy Duty Pavments “, Presented For The 2004 Faa Worldwide Airport Tecnology Transfer Conference, Atlantic City, USA.

]7[ Serfas, J.P, And Samanos, J. )1996( "Finer-Modified Asphalt concrete Characteristic, Applications And Behaviour ", Jornal Of The Association Of Asphalt Paving Tecnologists, Vol. 65 , PP.230 193.

]8[ Sheng Zhao, Baoshan Huang, Xiang Shu, Philip Ye, )2014( "Laboratory Investigation of BioChar Modified 1 Asphalt Mixture.", pp 1-20. 